\title{
FAST ${ }^{14}$ C SAMPLE PREPARATION OF ORGANIC MATERIAL
}

\author{
HELMUT DÖRR, BERND KROMER and KARL OTTO MÜNNICH \\ Institut für Umweltphysik der Universität Heidelberg \\ Im Neuenheimer Feld 366, 6900 Heidelberg (FRG)
}

\begin{abstract}
A fast ${ }^{14} \mathrm{C}$ sample preparation technique for organic material in conventional ${ }^{14} \mathrm{C}$ counting is described. The basic difference from conventional preparation is oxidation of the organic substances in a closed system under an oxygen pressure of ca 10 bars. After the explosion-like combustion, the reaction products $\mathrm{SO}_{2}$ and $\mathrm{NO}_{2}$ are oxidized immediately to $\mathrm{SO}_{4}^{2-}$ and $\mathrm{NO}_{3}^{-}$and precipitated on the wall of the reaction vessel. The residual gas mixture is passed first through a cold trap at $-78^{\circ} \mathrm{C}$ to remove water vapor and then through an activated charcoal column at $0^{\circ} \mathrm{C}$ for purification. $\mathrm{CO}_{2}$ is removed from the remaining $\mathrm{O}_{2}-\mathrm{CO}_{2}$ gas mixture in a $\mathrm{LN}_{2}$ trap at a pressure of $\simeq 100 \mathrm{mbar}$. With this method sample preparation time is reduced from ca $10 \mathrm{hr}$ to ca $1 \mathrm{hr}$. The efficiency and reproducibility of the procedure is shown with ${ }^{14} \mathrm{C}$ and ${ }^{13} \mathrm{C}$ measurements of a sugar-carbon standard. The results obtained by the new technique agree well with conventionally prepared wood and bone samples.
\end{abstract}

\section{INTRODUCTION}

In conventional ${ }^{14} \mathrm{C}$ counting, the established ${ }^{14} \mathrm{C}$ sample preparation technique for organic material (wood, bone, coal, soil and plant material) is burning the sample in an $\mathrm{O}_{2}$ stream, cleaning the evolved $\mathrm{CO}_{2}$ by chemical absorption or precipitation in alkaline solution and recovering the $\mathrm{CO}_{2}$ by acidification in a vacuum extraction system (Münnich, 1957). Using $\mathrm{CO}_{2}$ as a counting gas requires a highly efficient purification of the sample from $\mathrm{NO}, \mathrm{NO}_{2}, \mathrm{SO}_{2}$ and other electronegative impurities. The nitrogen and sulfur content of organic material is in the order of percent, while the concentration of electronegative impurities in the counting gas should be less than some ppm (Brenninkmeijer \& Mook, 1979). During purification, however, a considerable loss of $\mathrm{CO}_{2}$ should be avoided to prevent isotope fractionation. These requirements lead to an extensive preparation procedure and a preparation time of at least 10 hours.

An alternative technique (bomb combustion) of ${ }^{14} \mathrm{C}$ sample preparation in $\mathrm{CO}_{2}$ proportional and liquid scintillation counting (LSC) was described by Switsur et al (1970), Burleigh (1972), Switsur (1972) and Switsur et al (1974).

We describe a fast ${ }^{14} \mathrm{C}$ sample preparation technique for organic material in conventional $\mathrm{CO}_{2}$ proportional counting. The basic difference from conventional preparation (burning of the sample in an $\mathrm{O}_{2}$ stream) is oxidation of organic substances in a closed system and preparation time is reduced to ca 1 hour.

\section{MATERIALS AND METHODS}

Figure 1 shows the experimental setup for ${ }^{14} \mathrm{C}$ sample preparation of organic material. The combustion bomb (Parr Oxygen Combustion Bomb 1121, H Kürner, Rosenheim, FRG) is made of specially selected stainless 


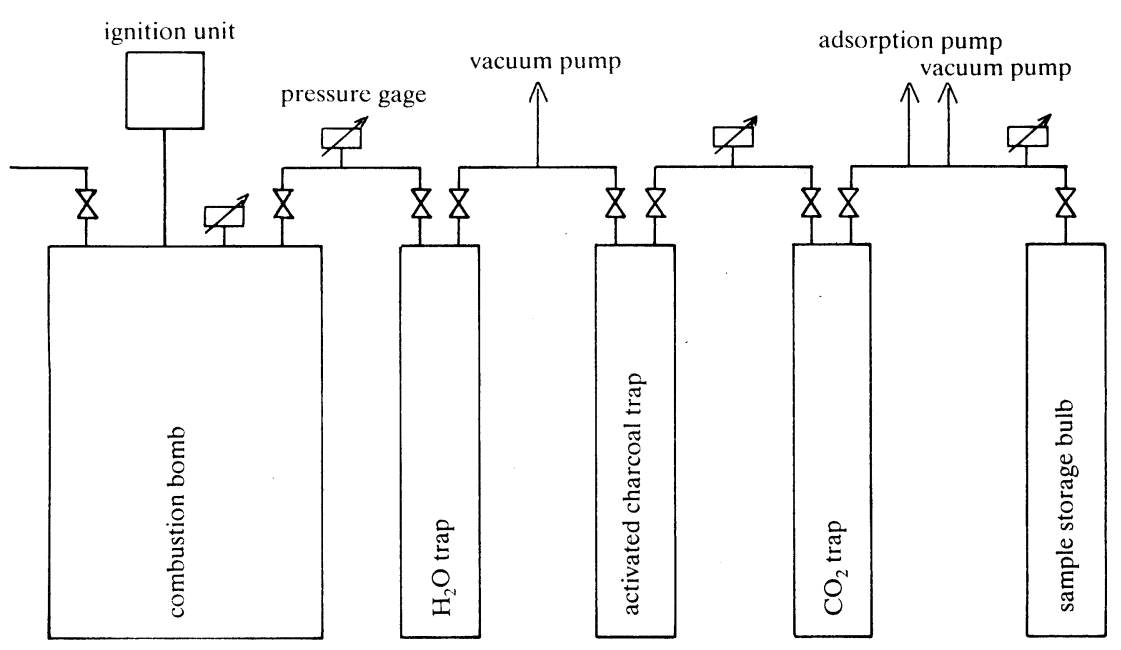

Fig 1. Schematic diagram of the experimental setup

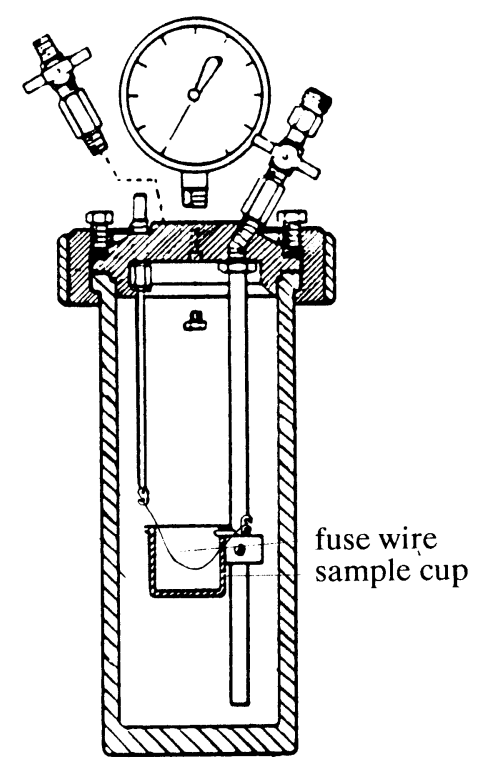

Fig 2. Schematic diagram of the oxygen combustion bomb (Parr Operating Instructions No210M) 
steel; all other parts of the preparation system are made of standard borosilicate glass. The organic sample is oxidized in a combustion bomb of $1850 \mathrm{ml}$ volume at an oxygen pressure of ca 10 bars. The sample is compressed, together with a fuse wire in a stainless steel sample cup (Fig 2). Maximum sample size is ca $10 \mathrm{~g}$ of organic material. The sample cup has a volume of $46 \mathrm{ml}$. The bomb is fired by an external ignition unit providing the proper electrical current to burn the sample. Pressure rises rapidly during the first seconds after firing due to the increasing temperature of the gases. In most instances, combustion is complete after the first minute.

$\mathrm{SO}_{2}, \mathrm{NO}, \mathrm{NO}_{2}$ and $\mathrm{H}_{2} \mathrm{O}$ are generated during the combustion. In excess of oxygen and water vapor (ca $5 \mathrm{ml}$ of distilled water are added before ignition), these contaminants precipitate immediately on the wall of the reaction vessel. The residual gas mixture is passed through a cold trap at $-78^{\circ} \mathrm{C}$ (acetone-dry-ice mixture) to remove water vapor. The flow rate is 0.8 $-1 \mathrm{~L} / \mathrm{min}$ at a pressure of $0.8-1 \mathrm{bar}$. The line pressure is controlled by the outlet valve of the combustion bomb. The cold trap has a total length of $130 \mathrm{~cm}$ and an inner diameter of $1 \mathrm{~cm}$. The gas is then passed through an activated charcoal column at $0^{\circ} \mathrm{C}$ (ice-water mixture) for further purification (Bruns, 1976). Gas purification with activated charcoal is routinely used in the Heidelberg ${ }^{14} \mathrm{C}$ laboratory since several years. The charcoal trap has a total length of $220 \mathrm{~cm}$ and an inner diameter of $0.9 \mathrm{~cm}$. It is filled with $45 \mathrm{~g}$ of Degusorb F12/470 (Degussa AG, Frankfurt, FRG). This activated carbon has a specific surface of $1.1 \mathrm{~m}^{2} / \mathrm{g}$, a grain size of ca $1 \mathrm{~mm}$ and a bulk density of $0.46 \mathrm{~g} / \mathrm{cm}^{3}$. The pressure at the outlet of the charcoal trap is set to be $50-$ $100 \mathrm{mbars}$.

Finally, $\mathrm{CO}_{2}$ is removed from the residual $\mathrm{CO}_{2}-\mathrm{O}_{2}$ gas mixture in a $\mathrm{LN}_{2}$ trap at a pressure of $50-100 \mathrm{mbars}$. The dimensions of this trap are comparable with the dimensions of the $\mathrm{H}_{2} \mathrm{O}$ trap. During the whole process, $\mathrm{O}_{2}$ is being removed continuously with a vacuum pump. At a final pressure of $20 \mathrm{mbars}$ (water vapor partial pressure), the combustion bomb is closed at the outlet valve. This pressure is reached after a processing time of ca 20 min. The final pressure of ca $1 \mathrm{mbar}$ at the outlet of the activated charcoal column is reached after an additional $10 \mathrm{~min}$. The $\mathrm{CO}_{2}$ trap with the frozen sample is evacuated to a pressure of $10^{-3} \mathrm{mbars}$ using a liquid $\mathrm{N}_{2}$ cooled adsorption pump.

The $\mathrm{CO}_{2}$ sample is expanded in a pre-evacuated storage bulb. The amount of $\mathrm{CO}_{2}$ is estimated from pressure, temperature and volume of the storage bulb $(\simeq 5 \mathrm{~L})$. The complete sample is again frozen to remove traces of trapped $\mathrm{O}_{2}$. The collected $\mathrm{CO}_{2}$ can then be used as a counting gas in a conventional $\mathrm{CO}_{2}$ proportional counter system without any further purification.

For regeneration, the activated charcoal column is heated at $400^{\circ} \mathrm{C}$ and flushed with $\mathrm{N}_{2}$ during cooling to room temperature to remove trapped contaminants. The total time for sample preparation is ca $1 \mathrm{hr}$; the time for regeneration of the activated charcoal trap is ca $30 \mathrm{~min}$. 
RESULTS

To design the length and inner diameter of the water vapor and $\mathrm{CO}_{2}$ trap, the efficiency is estimated from the diffusion relaxation time, $\tau \simeq r^{2} /(6 D)$, where $r$ is the radius of the trap and $D$ is the molecular diffusion coefficient of water vapor or $\mathrm{CO}_{2}$, and the diffusion relaxation length $\mathrm{l} \simeq \mathrm{v} \tau$, where $\mathrm{v}$ is the gas velocity. The relaxation length, 1 , is the distance along which the concentration of water vapor or $\mathrm{CO}_{2}$ decreases to $1 / \mathrm{e}$ of the initial content. The relaxation length of the $\mathrm{H}_{2} \mathrm{O}$ trap is ca $4 \mathrm{~cm}$ and of the $\mathrm{CO}_{2}$ trap ca $6 \mathrm{~cm}$. At a total length of $130 \mathrm{~cm}$ the $\mathrm{CO}_{2}$ and $\mathrm{H}_{2} \mathrm{O}$ concentration at the outlet of the trap is negligible. This was confirmed by separate experiments: water vapor saturated $\mathrm{N}_{2}$ or pure $\mathrm{CO}_{2}$ was passed through two traps in series and the amount of $\mathrm{H}_{2} \mathrm{O}$ and $\mathrm{CO}_{2}$ in the traps was measured. At flow rates of $0.5-1 \mathrm{~L} / \mathrm{min}, \mathrm{H}_{2} \mathrm{O}$ or $\mathrm{CO}_{2}$ could not be detected in the second trap.

To measure the amount of $\mathrm{SO}_{2}$ and $\mathrm{NO}_{2}$ removed from the combustion gas inside the combustion bomb, $50 \mathrm{ml}$ of distilled water were added to the combustion vessel and mixed with the precipitated $\mathrm{SO}_{4}^{2-}$ and $\mathrm{NO}_{3}^{-} \cdot \mathrm{SO}_{2}$ and $\mathrm{NO}_{2}$ removed by the activated charcoal trap were sampled by heating the trap and collecting the desorbed gases in a flask filled with $5 \mathrm{ml}$ of distilled water. The flask was shaken for $24 \mathrm{hr}$ to enable complete oxidation of $\mathrm{SO}_{2}$ and $\mathrm{NO}_{2}$ to $\mathrm{SO}_{4}^{2-}$ and $\mathrm{NO}_{3}^{-}$. The same technique was used to determine the $\mathrm{SO}_{2}$ and $\mathrm{NO}_{2}$ content in the $\mathrm{CO}_{2}$ sample. The $\mathrm{SO}_{4}^{2-}$ and $\mathrm{NO}_{3}^{-}$concentration of the liquid samples were measured by ion chromatography.

The total amount of nitrogen and sulfur desorbed from the charcoal trap was $<1 \%$ of the amount precipitated at the walls of the combustion vessel. The $\mathrm{SO}_{2}{ }^{-}$and $\mathrm{NO}_{2}$ concentration in the $\mathrm{CO}_{2}$ sample was $<0.1 \mathrm{ppm}$.

The results obtained from samples with a sulphur and nitrogen content of ca $1 \%$ show that practically all contaminants are already removed in the combustion bomb and that only traces of $\mathrm{SO}_{2}$ and $\mathrm{NO}_{2}$ must be trapped in the activated charcoal column. The sample loss in the activated charcoal trap was determined by measuring the amount of $\mathrm{CO}_{2}$ desorbed during regeneration of the charcoal column. Ca $2 \%$ of the sample is lost when all gases are drawn through the charcoal until a final pressure of $1 \mathrm{mbar}$ is reached at the outlet of the charcoal trap. The sample loss increases to ca $8 \%$ at a final pressure of 5 mbars. These values are considered an upper limit, because we cannot completely exclude the possibility that traces of charcoal are being oxidized to $\mathrm{CO}_{2}$ when the trap is heated to $400^{\circ} \mathrm{C} . \delta^{13} \mathrm{C}$ measurements show that the trapped $\mathrm{CO}_{2}$ is enriched in ${ }^{13} \mathrm{C}$ by $1.1 \pm 0.1 \%$. The difference in $\delta^{13} \mathrm{C}$ between the sample and the trapped $\mathrm{CO}_{2}$ was independent of the percentage loss of $\mathrm{CO}_{2}$ in the charcoal column. This supports the assumption that excess $\mathrm{CO}_{2}$ is produced by heating the charcoal trap. The observed difference in $\delta^{13} \mathrm{C}$ will shift the ${ }^{13} \mathrm{C}$ content of the sample by $<0.1 \%$. To prevent memory effects, the charcoal trap is flushed with $\mathrm{N} 2$ before each sample preparation.

${ }^{14} \mathrm{C}$ and ${ }^{13} \mathrm{C}$ measurements of a sugar carbon substandard obtained by this technique agree well with published data and show that isotope fractionation and contamination are negligible (Table 1). ${ }^{14} \mathrm{C}$ and ${ }^{13} \mathrm{C}$ measurements of wood and bone samples obtained with this technique agreed, within a statistical counting error of ca $4 \%$, with conventionally prepared ${ }^{14} \mathrm{C}$ samples and within $\pm 0.15 \%$ of $\delta^{13} \mathrm{C}$ samples. 
TABLE 1

Comparison of ${ }^{14} \mathrm{C}$ and ${ }^{13} \mathrm{C}$ measurements of a sugar carbon standard with published data

\begin{tabular}{ccc}
\hline & Standard & This method \\
\hline$\Delta^{14} \mathrm{C}[\%]$ & $362 \pm 3$ & $364 \pm 5$ \\
$\delta^{13} \mathrm{C}[\% \mathrm{o}]$ & $-19.47 \pm .54$ & $-19.56 \pm .03$ \\
\hline
\end{tabular}

\section{CONCLUSIONS}

The described method proves to be a convenient and accurate ${ }^{14} \mathrm{C}$ sample preparation technique for organic samples in conventional ${ }^{14} \mathrm{C}$ counting. The method is successfully tested with wood and bone (collagen) samples, fresh plant material (beech leaves and spruce needles) and soil organic material. The organic carbon content in soil samples, however, should not be $<1.5 \%$ to prevent incomplete combustion. By minimizing the volume of the combustion bomb and traps, this technique may also be used to combust low volume samples for ${ }^{14} \mathrm{C}$ dating with accelerator mass spectrometry (AMS) (Grabitz, 1988).

\section{ACKNOWLEDGMENTS}

This study was partly funded by the State Government of BadenWürttemberg (FRG), grant no. PW85009.

\section{REFERENCES}

Brenninkmeijer, C A M and Mook, W G, 1979, The effect of electronegative impurities on $\mathrm{CO}_{2}$ proportional counting: An on-line purity test counter, in Berger, $\mathrm{R}$ and Suess, $\mathrm{H} \mathrm{E}$, eds, Radiocarbon dating, Internatl ${ }^{14} \mathrm{C}$ conf, 9th, Proc: Berkeley, Univ California Press, $\mathrm{p}$ 185-196.

Bruns, M, (ms) 1976, Gaschromatographie mit ${ }^{222} \mathrm{Rn}$ : Univ Heidelberg, AERE, Harwell, LB/ G910/049.

Burleigh, R, 1972, Bomb combustion of radiocarbon samples, in Rafter, T A and GrantTaylor, T, eds, Internatl conf on ${ }^{14} \mathrm{C}$ dating, 8th, Proc: Wellington, Royal Soc New Zealand, $v 1, \mathrm{p} 110-119$.

Grabitz, D, (ms) 1988, Aufbereitung von verschiedenen organischen Proben für die ${ }^{14} \mathrm{C}$ Altersbestimmung durch Beschleunigermassenspektroskopie. Messung von planktonischen Foraminiferen arktischer Sedimente: Univ Heidelberg.

Münnich, K O, (ms) Messung natürlichen Radiokohlenstoffs mit einem $\mathrm{CO}_{2}$-ProportionalZählrohr. Einige Anwendungen der Methode: PhD dissert, Univ Heidelberg.

Switsur, V R, 1972, Bomb combustion for radiocarbon dating, in Rafter, T A and GrantTaylor, $\mathrm{T}$, eds, Internatl conf on ${ }^{14} \mathrm{C}$ dating, 8th, Proc: Wellington, Royal Soc New Zealand, v 1, p 120-132.

Switsur, V R, Burleigh, R, Meeks, N and Cleland, J M, 1974, A new sample combustion bomb for radiocarbon dating: Internatl Jour Applied Radiation Isotopes, v 25, p 113-117.

Switsur, V R, Hall, M A and West, R G, 1970, University of Cambridge natural radiocarbon measurements IX: Radiocarbon, v 12, no.2, p 590-598. 